\title{
Genetic Variability, Heritability and Cluster Analysis in Some Accessions of Pepper (Capsicum Spp)
}

\author{
E. B. Ishaya, A. S. Gana, D. A. Ayeleke, O. O. Obogun, M. O. Akinyele, G. A. Idowu
}

\begin{abstract}
Morphological and cytological evaluation of pepper accessions is important for breeding and improvement programme on the crop. The lack of understanding on the genetic variation of pepper accessions has led to little progress in breeding and improvement of the crop. Therefore, the objectives of this study were to characterize some available pepper accessions based on morphological, agronomic and cytological characters and their suitability for subsequent use in breeding programme. The field experiment was conducted at GidanMangoro, Bosso Local Government Area,Minna, Niger State, in a randomized complete block design with three replications. The cytological investigation was carried out at the laboratory of the Department of Crop Production, Federal University of Technology, Minna, Niger State. Data were collected on plant height, leaf length, leaf width, days to first flowering, days to $50 \%$ flowering, fruit length, fruit girth, number of fruits, average fruit weight average seed weight and plant growthhabit. From Analysis of Variance, genotypic variance $(\mathrm{GV})$, phenotypic variance $(\mathrm{PV})$, genotypic coefficient of variation (GCV), Phenotypic Coefficient of Variation (PCV),heritability and genetic advance were estimated. There were significant differences in the accessions studied. Analysis of variance for genetic diversity revealed that plant height, leaf width and all yield components studied contributed to genetic diversity. The highest heritability value was observed in average fruit weight per plant (98 \%). Accessions DKD-RD and DG-SB performed best as characterized by early days to first flowering, number of fruits per plant, number of branches and fruit girth. The variance of component of variation result revealed that PCV values were greater than those of GVC. Also, genetic advance (GA) was higher than heritability. The cytological study showed that at meiosis, two daughter cells divides and formed four daughter cells thereby contributing to genetic variation. Based on the findings of this research work, it is recommended that breeders should collect germplasm from DKD-RD，DG-SB， DSKT-RD and DADAM for further breeding and improvement programme of the crop.

Index Terms - genetic variation, agro-morphological traits, cytological behaviours, heritability; pepper (Capsicum spp).
\end{abstract}

\section{INTRODUCTION}

Pepper belong to the genus Capsicum and member of the nightshade family Solanaceae. This genus also called the

\footnotetext{
E. B. Ishaya*, Department of Crop Production, Federal University of Technology, PMB 65, Minna, Nigeria

A. S. Gana, Department of Crop Production, Federal University of Technology, PMB 65, Minna, Nigeria

D. A. Ayeleke, Federal Department of Agriculture, Federal Ministry of

Agriculture \& Rural Development, PMB 135, Garki, Abuja

O. O. Obogun, Department of Plant Science,Ahmadu Bello University,

Zaria, Kaduna State

M. O. Akinyele, Agricultural Biotechnology Department, National

Biotechnology Development Agency, Lugbe, Abuja

G. A. Idowu, Seed Certification Department, National Agricultural Seed Council, Sheda, Abuja
}

chilli pepper [1] originated from Central and South America [2]. There are about thirty species in the genus Capsicum and several species have been domesticated to produce many cultivated types which range from mild to hot [3]. Fruit characters have been extensively used in the taxonomy of the family Solanaceae[4].Most natural populations of pepper are diploid and have the same chromosome number, $2 n=24$ [2, 5]. Nigeria is known to be one of the major producers of pepper in the world accounting for about $17 \%$ with 78,462 $\mathrm{t}$ from 90,000 ha of the world production [6]. Chillies are largely grown in many parts of Nigeria and the major area of production is the northern region between latitude $10 \mathrm{o} \mathrm{N}$ and $12030^{\prime} \mathrm{N}$ [7]. The chilli peppers are excellent source of nutrition for humans, a rich source of most B vitamins and vitamin B6 in particular [8]. They can be eaten raw, cooked or processed into powder form for culinary uses [9].

Estimating the amount of genetic variability and determining the nature of the association between variables are very important steps in selection and improvement programme of this important crop. Furthermore, the success of any selection programme depends largely on the amount of genetic variability existing in the population. Cytological and agro-morphological traits have been found to provide a good assessment of variability in capsicum species $[10,11]$.

\section{MATERIALS AND METHODS}

\section{Location of Experimental Site}

The research was conducted at GidanMangoro village, Bosso Local Government Area of Minna, located at an elevation of 482 metres above sea level in the Southern Guinea Savanna zone of Nigeria and lying between latitude 9o 33'57.69'N, longitude 6o 29'19.896'E. The elevation of the site was tracked using GPS (Geographical Positioning System, Garmin Taiwan). The Cytological investigation was carried-out at the Laboratory of the Department of Crop Production, Federal University of Technology GidanKwano Campus, Minna, Niger State of Nigeria.

\section{Treatment and Experimental Design}

Ten accessions of chilli pepper were collected from local farmers in different locations of Northern Guinea Savanna and Sudan Savanna of Nigeria. Seed of four accessions were collected from Kaduna State [Dan-BirninGwari (DBG), Dan-Zaria 'Tatashe (DZ-TSH), Dan-Kaduna (DKD), Dan-Gada' Shombo' (DG-SB)], three accessions Sokoto State [Dan-Sokoto 'Rodo' (DSKT-RD), Dan-Sokoto 'Tatashe' (DSKT-TSH) and Dan Sokoto 'Shombo' 
(DSKT-SB)], one from Kano State [Dan Kano (DKN)], one from Adamawa State [Dan-Adamawa (DADAM)], and one from Katsina State [Dan-Katsina (DKST)]. The planting was done using Randomized Complete Block Design with three replications.

Data Collection and Statistical Analysis

Data were collected on plant height, leaf length, leaf width, days to first flowering, days to $50 \%$ flowering, fruit length, fruit girth, number of branches per plant, number of fruit per plant, average fruit weight per plant and average seed weight per plant. All data collected were subjected to analysis of variance (ANOVA) using SAS statistical package [12]. The means were separated by Duncan's Multiple Range Test (DMRT)[13] at 5\% level of probability. The photomicrographs of the cytological observation were taken using the Olympus microscope with a Sony digital camera (16.1 Mega pixels).

\section{RESULTS}

The agronomic performance of the ten pepper accessions studied revealed that the accessions differed significantly $(\mathrm{p}<0.05)$ in all the traits studied (Table 1). The tallest plant was accession DSKT-SB which differed significantly with the other accessions except for DG-SB which showed no significant difference. Accession with the highest leaf length was DSKT-TSH which showed no significance difference with all the other nine accessions except for DADAM which differed significantly. The highest leaf weight was observed in DKD-RD, early days to first flowering and days to $50 \%$ flowering were noted in accessions DG-SB and DBG respectively. DKST recorded the highest number of branches and number of fruit. DSKT-TSH had the highest average fruit weight per plant and differed significantly with all the other accessions except for DZ-TSH which showed no significant difference. For seed weight per plant, accession DZ-TSH recorded the average seed weight and showed no significant difference with DSKT-TSH but differed significantly with all the other remaining eight accessions.

Table 1: Mean values for agronomic traits (quantitative) of the ten pepper accessions studied ACCESS

\begin{tabular}{|c|c|c|c|c|c|c|c|c|c|c|c|}
\hline & PHT & $\mathbf{L L}$ & $\mathbf{L W}$ & DFF & DF50\% & FL & FG & NOB & NOF & AFWT & $\overline{\text { ASDWT }}$ \\
\hline & $47.39^{\mathrm{bc}}$ & $11.85^{\mathrm{ab}}$ & $4.44^{\mathrm{c}}$ & $86.00^{a b}$ & $106.00^{\mathrm{ab}}$ & $4.71^{\mathrm{de}}$ & $1.13^{\mathrm{fg}}$ & $8.00^{\mathrm{a}}$ & $54.33^{\mathrm{a}}$ & $14.66^{\mathrm{d}}$ & $2.32^{\mathrm{e}}$ \\
\hline DSKT-TSH & $38.12^{\circ}$ & $12.87^{\circ}$ & $4.93^{u}$ & $86.67^{\text {au }}$ & 106.00 & $8.55^{\circ}$ & $4.44^{\prime \prime}$ & $4.67^{v-u}$ & 12.00 & $261.01 \mathrm{a}$ & $7.87^{a}$ \\
\hline DG-SB & $52.91^{\circ}$ & $12.02^{\mathrm{u \nu}}$ & $4.61^{\complement}$ & $93.67^{\circ}$ & $108.67^{\mathrm{a \nu}}$ & $9.77^{\circ}$ & $2.29^{\circ}$ & $4.00^{--}$ & $33.33^{\circ}$ & $93.42^{\circ}$ & $5.98^{\circ}$ \\
\hline DADAM & $47.63^{\mathrm{u}}$ & $10.62^{\circ}$ & $4.26^{\circ}$ & $91.67^{\circ u}$ & $105.57^{\circ}$ & $7.34^{2}$ & $1.33^{-1}$ & $5.00 \mathrm{bc}$ & $37.33^{\circ}$ & $33.31^{\circ}$ & $5.18^{u}$ \\
\hline DZ-TSH & $38.77^{4}$ & $12.72^{\circ}$ & 4.54 & $89.00^{\circ \omega}$ & $107.67^{\text {uv }}$ & $6.39^{\circ}$ & $4.51^{\circ}$ & $3.67^{u}$ & $12.33^{2}$ & $253.84^{\prime \prime}$ & $8.070^{\circ}$ \\
\hline DKN & $49.12^{\text {u }}$ & $11.77^{\text {au }}$ & 4.51 & $86.67^{\circ}$ & $107.67^{a \nu}$ & $6.79^{\circ}$ & $0.91^{5}$ & $7.33^{\circ}$ & $30.67^{\circ}$ & $23.27^{\circ}$ & $3.09^{\mathrm{u}}$ \\
\hline DSKT-SB & $56.56^{\prime \prime}$ & $12.28^{a v}$ & $5.88^{\text {au }}$ & $87.00^{\circ \omega}$ & $107.67^{a \nu}$ & $8.84^{\circ u}$ & $1.90^{\mathrm{w}}$ & $4.00^{-2}$ & $27.67^{\circ}$ & $59.18^{\longleftarrow}$ & $3.00^{\mathrm{u}}$ \\
\hline DBG & $46.48^{\mathrm{c}}$ & $11.63^{\mathrm{ab}}$ & $4.33^{\mathrm{c}}$ & $87.00^{\mathrm{ab}}$ & $109.00^{\mathrm{ab}}$ & $5.23^{a}$ & $1.58^{\mathrm{ed}}$ & $5.67^{\mathrm{D}}$ & $31.00^{\mathrm{D}}$ & $31.80^{\mathrm{d}}$ & $4.07^{\mathrm{cd}}$ \\
\hline DKD-RD & $38.67^{\circ}$ & $11.30^{\mathrm{av}}$ & $6.56^{\prime \prime}$ & $88.00^{\text {av }}$ & $110.33^{\circ}$ & $1.85^{\prime}$ & $2.13^{-}$ & $3.33^{\circ}$ & $37.00^{\circ}$ & $33.20^{\circ}$ & $0.71^{1}$ \\
\hline DSKT-RD & $40.28^{\circ}$ & $11.73^{\circ}$ & $6.35^{\mathrm{u}}$ & $83.33^{\circ}$ & $108.67^{\circ}$ & $3.65^{\circ}$ & $3.70^{\circ}$ & $4.00^{\circ}$ & $30.33^{\circ}$ & $105.19^{\circ}$ & $3.39^{\mathrm{u}}$ \\
\hline Mean & 45.593 & 11.879 & 5.041 & 86.0 & 106.0 & 6.312 & 2.392 & 4.967 & 30.599 & 90.888 & 4.368 \\
\hline$\pm \mathbf{S E}$ & 1.90 & 0.57 & 0.33 & 2.85 & 1.29 & 0.37 & 0.13 & 0.34 & 5.01 & 7.10 & 0.39 \\
\hline $\mathrm{CV}$ & 7.202 & 8.2734 & 11.35 & 6192 & 2.0779 & 10.0 & 6 & 11.6 & 3 & 3.5384 & 15.4 \\
\hline
\end{tabular}

Means followed by the same letter(s) within the column are not significantly different $(p=0.05)$ by Duncan Multiple Range Test.

$\mathrm{PHT}=$ plant height, $\mathrm{LL}=$ leaf length, $\mathrm{LW}=$ leaf width, $\mathrm{DFF}=$ days to first flowering, $\mathrm{D} 50 \% \mathrm{~F}=$ days to $50 \%$ flowering, $\mathrm{FL}=$ fruit length, $\mathrm{FG}=$ fruit girth, $\mathrm{NOB}=$ number of branches, $\mathrm{NOF}=$ number of fruits/plant, $\mathrm{AFWT}=$ average fruit weight/plant, ASDWT $=$ average seed weight/plant. DKST $=$ Dan Katsina, DSKT-TSH = Dan Sokoto 'Tatashe', DG-SB= Dan Gada'Shombo', DADAM= Dan Adamawa, DZ-TSH= Dan Zaria 'Tatashe' DKN= Dan Kano, DSKT-SB= Dan Sokoto 'Shombo', DBG= Dan BirninGwari, DKD- RD= Dan Kaduna 'Rodo', DSKT-RD= Dan Sokoto 'Rodo'.

Variance Component for Genetic Diversity among the Ten Pepper Accessions

The highest genotypic variance were observed in number of fruit per plant, average fruit weight per plant and plant height, while leaf length, days to first flowering, days to $50 \%$ flowering and fruit girth showed low genotypic variance (Table 2). Results of the phenotypic variance showed that average fruit weight per plant had the highest value and next was number of fruits per plantwhile the least values were observed in plant height and days to first flowering, but the remaining seven traits showed a very low phenotypic influence. Phenotypic coefficients of variation were observed to be higher than genotypic coefficient of variation. Similarly, the results of genetic advance were higher than that of heritability with exception on fruit length per plant, fruit girth, number of branches per plant, number of fruit per plant, average fruit eight and average seed weight which showed a lower genetic advance in relation to heritability. 
Table 2: Variance component for genetic diversity among the accessions studied

\begin{tabular}{lllllll} 
Traits & GV & PV & GCV & PCV & $\mathbf{H}^{\mathbf{2}(\%)}$ & GA \\
\hline PHT & 37.83 & 48.61 & 13.49 & 15.29 & 78.0 & 78.22 \\
LL & 0.11 & 1.08 & 2.79 & 8.75 & 10.0 & 22.28 \\
LW & 6.00 & 6.33 & 48.5 & 49.92 & 9.50 & 12.40 \\
DFF & 0.51 & 24.91 & 0.83 & 5.80 & 2.00 & 10.27 \\
D50\%F & 0.60 & 5.61 & 0.73 & 2.23 & 12.0 & 13.88 \\
FL & 6.01 & 6.41 & 38.85 & 40.12 & 94.0 & 12.43 \\
FG & 1.79 & 1.84 & 55.98 & 56.76 & 97.0 & 36.82 \\
NOB & 2.39 & 2.73 & 31.11 & 33.18 & 88.0 & 49.56 \\
NOF & 124.00 & 199.8 & 36.45 & 46.19 & 62.0 & 25.55 \\
AFWT & 85.31 & 86.82 & 101.60 & 102.50 & 98.0 & 17.55 \\
ASDWT & 5.56 & 6.02 & 53.96 & 56.15 & 92.0 & 11.42 \\
\hline
\end{tabular}

$\mathrm{PHT}=$ plant height, $\mathrm{LL}=$ leaf length, $\mathrm{LW}=$ leaf width, $\mathrm{DFF}=$ days to first flowering, $\mathrm{D} 50 \% \mathrm{~F}=$ days to $50 \%$ flowering, $\mathrm{FL}=$ fruit length, $\mathrm{FG}=$ fruit girth, $\mathrm{NOB}=$ number of branches, $\mathrm{NOF}=$ number of fruits/plant, $\mathrm{AFWT}=$ average fruit weight per plant, ASDWT $=$ average seed weight per plant. $\mathrm{GV}=$ genotypic variance, $\mathrm{PV}=$ phenotypic variance, $\mathrm{GCV}=$ genotypic coefficient of variation, $\mathrm{PCV}=$ Phenotypic coefficient of Variation $\mathrm{H}_{\mathrm{b}}{ }_{\mathrm{b}}=$ heritability (\%).GA= genetic Advance

Cluster Groupings of the Accessions Based on five sub-groups. Sub-cluster 1, composed of DADAM and Quantitative Traits

The study revealed that there were three clusters. Cluster one consisted of DSKT-TSH and DZ-TSH, which had $6.14 \%$ similarity (Figure 1). The second cluster comprised of DKST, DADAM, DKN, DBG and DKD-RD accessions with 28.4 percentage similarities. However, within the group there were DBG, which were the most closely related accessions. This sub-cluster was then joined by DKN to form another sub-cluster. The next hierarchy of cluster was formed by the association of DKD-RD. Another sub-cluster was formed as a result of inclusion of DSKT-SB. Cluster 3, comprised DG-SB and DSKT-RD which consisted of $16.30 \%$ similarity.

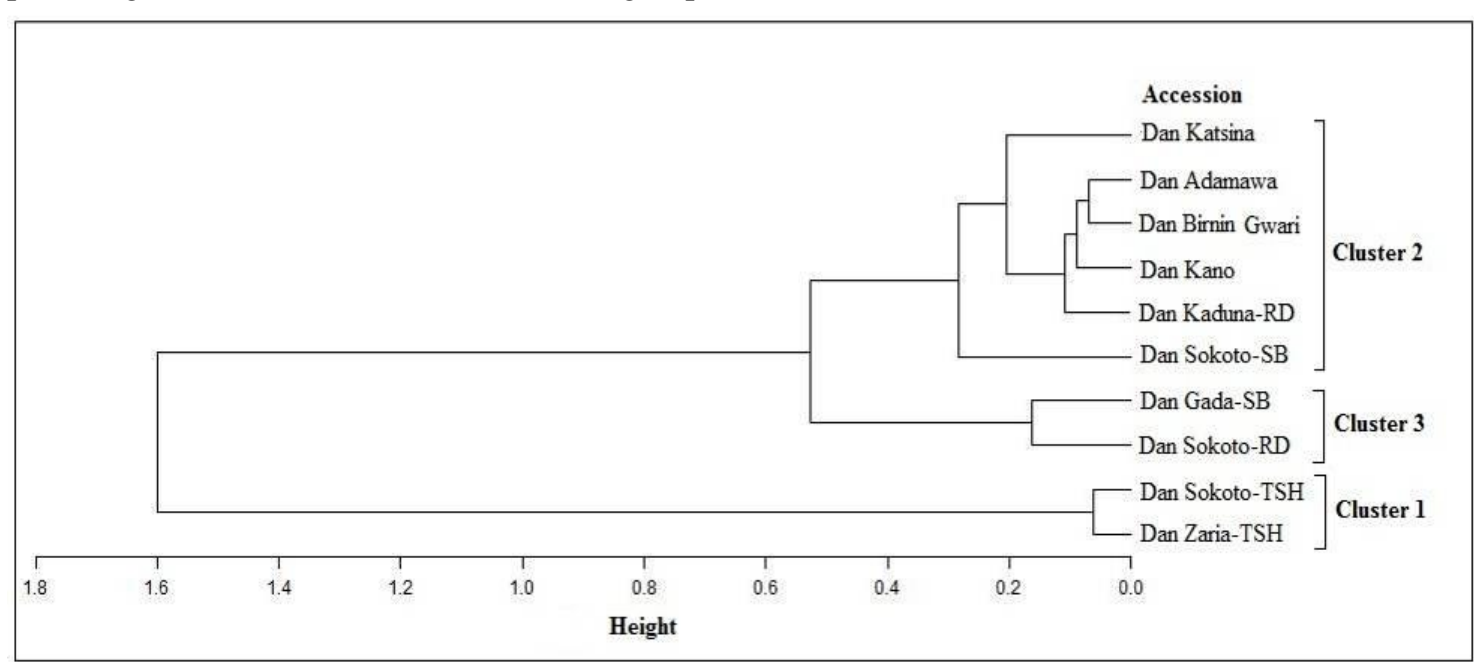

Figure 1: Dendogram of the ten pepper accessions inferred from morphological and yield (quantitative) traits using Unweighted Pair Group Method with Arithmetic (UPGMA) means

Descriptive cluster groupings of the accessions based on quantitative traits

Descriptive cluster grouping based on quantitative traits are presented in Table 3 . The result revealed that there were three clusters and each cluster showed a variation in mean and standard deviation among the ten accessions studied. Cluster one, comprised accession DSKT-TSH and DZ-TSH which were characterized with short plant height (38.4), a high mean value in traits such as plant leaf length (12.8), fruit length (7.50), fruit girth (4.50), average fruit weight per plant (257.40) and average seed weight per plant (8.00). The second cluster consisted of accession DKST, DBG, DSKT-SB, DG-SB and DSKT-RD and they are characterized by high mean in traits such as plant height (47.60), and

number of fruits per plant (36.30). These accessions showed an average mean in days to $50 \%$ flowering (107.70). The accessions also indicated the least mean in leaf length (11.60), fruit length (5.80), fruit girth (1.50) days to first flowering (87.70), average fruit weight per plant (32.60) and average seed weight per plant (3.10). Cluster three, comprised of DG-SB and DSKT-RD. These accessions are characterized by average mean value in traits such as plant height (46.60), leaf length (11.90), fruit length (6.70), fruit girth (3.00) and average seed weight per plant (4.70). Higher mean values were observed in traits such as days to first flowering (88.50) and days to $50 \%$ flowering (108.70). Number of branches per plant (4.00) showed the least value in this cluster. 
Genetic Variability, Heritability and Cluster Analysis in Some Accessions of Pepper (Capsicum Spp)

Table 3: Mean values and standard deviations used in classification of traits of the accessions studied (2016)

\begin{tabular}{|c|c|c|c|c|c|c|}
\hline \multirow[b]{2}{*}{ Parameter } & \multicolumn{2}{|c|}{ Cluster 1} & \multicolumn{2}{|c|}{ Cluster 2} & \multicolumn{2}{|c|}{ Cluster 3} \\
\hline & Mean & STD & Mean & STD & Mean & STD \\
\hline $\mathrm{PH}$ & 38.40 & 1.80 & 47.60 & 6.20 & 46.60 & 7.50 \\
\hline LL & 12.80 & 0.70 & 11.60 & 1.00 & 11.90 & 1.10 \\
\hline LW & 4.70 & 0.50 & 5.00 & 1.00 & 5.50 & 1.10 \\
\hline DFF & 87.80 & 5.30 & 87.70 & 4.40 & 88.50 & 6.00 \\
\hline $\mathrm{D} 50 \% \mathrm{~F}$ & 106.80 & 2.40 & 107.70 & 3.20 & 108.70 & 1.60 \\
\hline FL & 7.50 & 1.50 & 5.80 & 2.30 & 6.70 & 3.40 \\
\hline FG & 4.50 & 0.20 & 1.50 & 0.40 & 3.00 & 0.90 \\
\hline NOB & 4.20 & 0.80 & 5.60 & 1.80 & 4.00 & 0.60 \\
\hline $\mathrm{NOF}$ & 12.20 & 0.40 & 36.30 & 11.30 & 31.80 & 11.60 \\
\hline AFWT & 257.40 & 22.30 & 32.60 & 14.50 & 99.30 & 8.80 \\
\hline ASDWT & 8.00 & 1.00 & 3.10 & 1.50 & 4.70 & 1.50 \\
\hline
\end{tabular}

$\mathrm{STD}=$ Standard deviation

PHT= plant height, $\mathrm{LL}=$ leaf length, $\mathrm{LW}=$ leaf width, $\mathrm{DFF}=$ days to first flowering, $\mathrm{D} 50 \% \mathrm{~F}=$ days to $50 \%$ flowering, $\mathrm{FL}=$ fruit length, $\mathrm{FG}=$ fruit girth, $\mathrm{NOB}=$ number of branches, $\mathrm{NOF}=$ number of fruits/plant, $\mathrm{AFWT}=$ average fruit weight/plant, ASDWT $=$ average seed weight/plant.

Descriptive cluster groupings of the accessions based on quantitative traits

The result revealed that there were three clusters and each cluster showed a variation in mean and standard deviation among the ten accessions studied (Table 4). Cluster one, comprised accessions DSKT-TSH and DZ-TSH which were characterized with short plant height (38.4), a high mean value in traits such as plant leaf length (12.8), fruit length (7.50), fruit girth (4.50), average fruit weight per plant (257.40) and average seed weight per plant (8.00). The second cluster consisted of accessions DKST, DBG, DSKT-SB, DG-SB and DSKT-RD and they are characterized by high mean in traits such as plant height (47.60), and number of fruits per plant (36.30). These accessions showed an average mean in days to $50 \%$ flowering (107.70). The accessions also indicated the least mean in leaf length (11.60), fruit length (5.80), fruit girth (1.50) days to first flowering (87.70), average fruit weight per plant (32.60) and average seed weight per plant (3.10). Cluster three, comprised of DG-SB and DSKT-RD. These accessions are characterized by average mean value in traits such as plant height (46.60), leaf length (11.90), fruit length (6.70), fruit girth (3.00) and average seed weight per plant (4.70). Higher mean values were observed in traits such as days to first flowering (88.50) and days to $50 \%$ flowering (108.70). Number of branches per plant (4.00) showed the least value in this cluster.

Table 4: Mean values and standard deviations used in classification of traits of the accessions studied (2016)

\begin{tabular}{|c|c|c|c|c|c|c|}
\hline \multirow[b]{2}{*}{ Parameter } & \multicolumn{2}{|c|}{ Cluster 1} & \multicolumn{2}{|c|}{ Cluster 2} & \multicolumn{2}{|c|}{ Cluster 3} \\
\hline & Mean & STD & Mean & STD & Mean & STD \\
\hline $\mathrm{PH}$ & 38.40 & 1.80 & 47.60 & 6.20 & 46.60 & 7.50 \\
\hline LL & 12.80 & 0.70 & 11.60 & 1.00 & 11.90 & 1.10 \\
\hline LW & 4.70 & 0.50 & 5.00 & 1.00 & 5.50 & 1.10 \\
\hline DFF & 87.80 & 5.30 & 87.70 & 4.40 & 88.50 & 6.00 \\
\hline $\mathrm{D} 50 \% \mathrm{~F}$ & 106.80 & 2.40 & 107.70 & 3.20 & 108.70 & 1.60 \\
\hline $\mathrm{FL}$ & 7.50 & 1.50 & 5.80 & 2.30 & 6.70 & 3.40 \\
\hline FG & 4.50 & 0.20 & 1.50 & 0.40 & 3.00 & 0.90 \\
\hline NOB & 4.20 & 0.80 & 5.60 & 1.80 & 4.00 & 0.60 \\
\hline $\mathrm{NOF}$ & 12.20 & 0.40 & 36.30 & 11.30 & 31.80 & 11.60 \\
\hline AFWT & 257.40 & 22.30 & 32.60 & 14.50 & 99.30 & 8.80 \\
\hline ASDWT & 8.00 & 1.00 & 3.10 & 1.50 & 4.70 & 1.50 \\
\hline
\end{tabular}

$\mathrm{STD}=$ Standard deviation

$\mathrm{PHT}=$ plant height, $\mathrm{LL}=$ leaf length, $\mathrm{LW}=$ leaf width, $\mathrm{DFF}=$ days to first flowering, $\mathrm{D} 50 \% \mathrm{~F}=$ days to $50 \%$ flowering, $\mathrm{FL}=$ fruit length, $\mathrm{FG}=$ fruit girth, $\mathrm{NOB}=$ number of branches, $\mathrm{NOF}=$ number of fruits/plant, $\mathrm{AFWT}=$ average fruit weight/plant, ASDWT $=$ average seed weight/plant.

Biplot Result of the Principal Components for Quantitative Traits 
The biplot result of the first and second principal components are presented (Figure 2.) For quantitative traits, the biplot of the first and second principal components revealed a high loading on the second positive dimension by traits such as plant height, number of branches, days to first flowering, fruit length, and average seed weight per plant contributing significantly to variability. However, traits such as number of fruits per plant, leaf length, and average fruit weight per plant contributed just a little of variability. At the second dimension, the axis was mostly characterized by vegetative growth, plant height, leaf length, days to first flowering, number of branches per plant, fruit girth, number of fruits per plant and average seed weight per plant. Although negative association existed in traits such as days to first flowering, leaf width, fruit girth and fruit weight per plant.

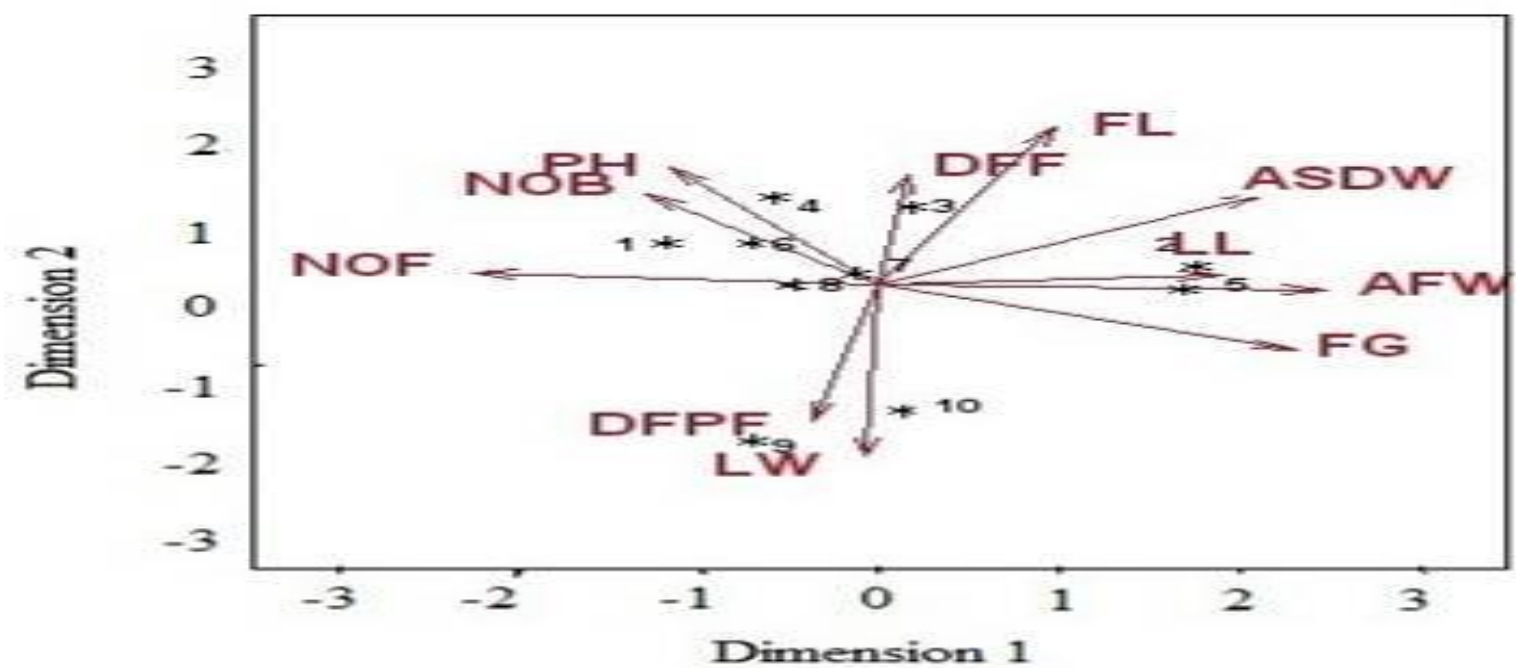

Figure 2: Biplot of the first and second principal components based on quantitative (morphological and yield) traits of ten pepper accessions.

Principal Components Based On Quantitative Traits

The results of principal component analyses for quantitative traits are presented in Table 5. Five principal component axes existed. The first PCA was characterized by positive loading on average fruit weight $(0.4601)$, fruit girth (0.4291), average seed weight per plant (0.3980), leaf length (0.3536), and days to first flowering (0.0274). This accounted for $41.82 \%$ of the total variation. The second PCA was loaded with fruit length (0.4559), plant height (0.3410), days to first flowering (0.3179), number of branches per plant (0.2637), average seed weight (0.2619), number of fruits per plant (0.0357) and leaf length (0.0308). The component contributed about $27.22 \%$ of the total variation. The third
PCA was characterized and loaded by days to first flowering (0.5567), days to $50 \%$ flowering (0.4012), plant height (0.3033), fruit length $(0.2378)$ and leaf width $(0.1868)$. This axis contributed about $14.12 \%$ of the variation observed. The fourth PCA was loaded by plant height (0.5329), leaf length (0.5147), fruit length (0.3354), leaf width (0.3147), days to 50 $\%$ flowering (0.0891) and number of branches (0.0660). The fourth axis accounted for about $8.71 \%$ of the total variation. Fifth component was characterized by positive loading on days to $50 \%$ flowering (0.7196), leaf length (0.3217), number of branches per plant (0.2902), days to first flowering (0.0836) and average seed weight (0.0517). The axis contributed about $4.41 \%$ of the total variation.

Table 5: Eigen vectors for principal component axes using quantitative and agronomic traits of the ten pepper accessions

\begin{tabular}{lccccc}
\hline Traits & Prin1 & Prin2 & Prin3 & Prin4 & Prin5 \\
\hline PHT & -0.2164 & 0.3410 & 0.3033 & 0.5329 & -0.0522 \\
LL & 0.3536 & 0.0308 & -0.1728 & 0.5147 & 0.3217 \\
LW & -0.0150 & -0.4942 & 0.1868 & 0.3147 & -0.4638 \\
DFF & 0.0274 & 0.3179 & 0.5567 & -0.4038 & 0.0836 \\
D50\%F & -0.0687 & -0.3927 & 0.4012 & 0.0891 & 0.7196 \\
FL & 0.1802 & 0.4559 & 0.2378 & 0.3354 & -0.1642 \\
FG & 0.4291 & -0.1893 & -0.0525 & -0.0571 & -0.1289 \\
NOB & -0.2410 & 0.2637 & -0.5470 & 0.0660 & 0.2902
\end{tabular}




\begin{tabular}{lccccc} 
NOF & -0.4216 & 0.0357 & -0.0711 & -0.1069 & -0.1498 \\
AFWT & 0.4601 & -0.0147 & -0.0938 & -0.0514 & -0.0299 \\
ASDWT & 0.3980 & 0.2619 & 0.0072 & -0.2167 & 0.0517 \\
\% variation & $\mathbf{4 1 . 4 8}$ & $\mathbf{2 7 . 2 2}$ & $\mathbf{1 4 . 1 2}$ & $\mathbf{8 . 7 1}$ & $\mathbf{4 . 4 1}$ \\
CV & $\mathbf{4 1 . 4 8}$ & $\mathbf{6 9 . 0 4}$ & $\mathbf{8 3 . 1 6}$ & $\mathbf{9 1 . 8 7}$ & $\mathbf{9 6 . 2 9}$ \\
\hline
\end{tabular}

$\mathrm{PHT}=$ plant height, $\mathrm{LL}=$ leaf length, $\mathrm{LW}=$ leaf width, $\mathrm{DFF}=$ days to first flowering, $\mathrm{D} 50 \% \mathrm{~F}=$ days to $50 \%$ flowering, $\mathrm{FL}=$ fruit length, $\mathrm{FG}=$ fruit girth, $\mathrm{NOB}=$ number of branches, $\mathrm{NOF}=$ number of fruits/plant, AFWT= average fruit weight/plant, ASDWT= average seed weight/plant.

Correlation Matrices for Quantitative Traits of the Studied Accessions

The result of correlation analysis (Table 6) showed that plant height had a significant positive association with the studied traits except for days to first flowering, fruit length, fruit girth, number of fruits per plant and average fruit weight per plant. Correlation in plant height and days to $50 \%$ flowering was significant $\left(0.76^{* * *}\right)$ and was the highest, followed by leaf length $\left(0.66^{* *}\right)$, next was leaf width $\left(0.50^{*}\right)$ and the least was number of branches per plant $\left(0.46^{*}\right)$. An association of leaf length and all the characters were positively and strongly significantly related except for traits like fruit length $\left(0.26^{\mathrm{ns}}\right)$, number of fruits $\left(0.39^{\mathrm{ns}}\right)$, average fruit weight per plant $\left(0.01^{\mathrm{ns}}\right)$, which were positive but non-significant. Leaf width showed a positive significant relationship for all the other character except for days to first flowering, days to $50 \%$ flowering, fruit length, number of branches and average seed weight which are positive and non-significantly correlated. Days to first flowering showed a highly significant association with all the other traits but non-significantly related to fruit length $\left(0.12^{\text {ns }}\right)$ and average seed weight per plant $\left(0.30^{\mathrm{ns}}\right)$. A positive and significant association occurred with days to $50 \%$ flowering and all the other studied parameters except for fruit length $\left(0.17^{\mathrm{ns}}\right)$, number of branches $\left(0.18^{\mathrm{ns}}\right)$ and average seed weight per plant $\left(0.23^{\text {ns }}\right)$ which showed a non-significant association. Fruit length showed a positive and strong significant relationship for two traits and a positive non-significant correlation with the remaining traits in the matrices; number of fruits per plant $\left(0.30^{\mathrm{ns}}\right)$, average fruit weight per plant $\left(0.39^{\mathrm{ns}}\right)$ and average seed weight per plant (0.06). Fruit girth matrix indicated that, a non-significant association existed in all the traits related to fruit girth. However, a significant negative correlation was observed in fruit weight. A strong positive correlation was traced to number of branches and average seed weight per plant alongside two positive and non-significant correlations with number of fruits per plant (0.12) and average fruit weight per plant (0.20). A positive and non-significant relationship existed in traits associated to number of fruits per plant, for instance traits related to number of fruits includes average fruit weight per plant (0.002) and average seed weight per plant (0.17). Lastly, a mutually positive and non-significant association was observed between average fruit weight per plant and average seed weight per plant $(0.003)$.

Table 6: Correlation matrices for quantitative traits of the ten pepper accessions studied

$\begin{array}{lllllllllll}\text { Traits } & \text { PHT } & \text { LL } & \text { LW } & \text { DFF } & \text { DF50\% } & \text { FL } & \text { FG } & \text { NOB } & \text { NOF } & \text { AFWT }\end{array}$

$\mathrm{LL}$

$$
0.66^{* *}
$$

LW $\quad 0.50^{*} \quad 0.95^{* *}$

DFF $\quad 0.35 \quad 0.57^{* *} \quad 0.21$

DF50\% $\quad .76^{* *} \quad 0.76^{* *} \quad 0.09$

$0.09 \quad 0.26$

FG

$0.04 \quad 0.04 \quad 0.50^{*}$

$$
0.12
$$$$
0.17
$$

NOB

$0.46^{*} \quad 0.70^{* *} \quad 0.09$

$$
0.68^{* *}
$$$$
0.97^{* *}
$$$$
0.86^{* * *}
$$

$0.48^{*} \quad 0.18 \quad 0.93^{* *}$

0.06

\section{NOF}

$0.29 \quad 0.04$

$0.93^{* *}$

$0.98^{* *} \quad 0.97^{* *}$

0.30

0.01

0.12

AFWT

$0.10 \quad 0.01$

$0.92^{* *}$

$0.99^{* *} \quad 0.57^{* *}$

0.39

$\mathbf{- 0 . 0 0 0 1} 0.20$

0.002 


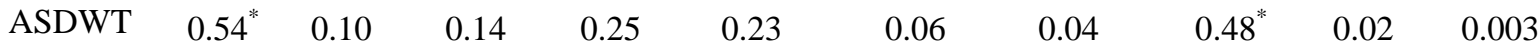

Note: * correlation is significant at $0.05, * *$ correlation is significant at 0.01 .

$\mathrm{PHT}=$ plant height, $\mathrm{LL}=$ leaf length, $\mathrm{LW}=$ leaf width, $\mathrm{DFF}=$ days to first flowering, DF50\%= days to $50 \%$ flowering, $\mathrm{FL}=$ fruit length, $\mathrm{FG}=$ fruit girth, $\mathrm{NOB}=$ number of branches, $\mathrm{NOF}=$ number of fruits/plant, $\mathrm{AFWT}=$ average fruit weight/plant, ASDWT=average seed weight per plant.

\section{Cytological Observation}

The result of the cytological study under a light microscope of the accession DKN revealed that at diakinenssis, chromosomes are mostly associated to bivalent from the first phase to the last phase of meiosis (Plate 1). At the first stage of meiosis, accession DKST was observed to be at the resting phase (Interphase I). In this stage no chromosomes were observed except a thread-like structure. Accession DSKT-SB showed a normal segregation pattern of chromosomes at metaphase I, with bivalent aligned at the spindle equator.
While at the early prophase chromosomes were observed forming a bivalent as in accession DK-RD and DBG. At early anaphase, two bipolar spindles were observed in accession DKN with chromosomes migrating to the poles while at late metaphase, chromosomes were observed in separate spindle dyad cell. At late telophase, accession DADAM showed a complete separation of the two sister's cell from each other. During the process of meiotic division accession DSKT-SB showed an abnormal disjoint resulting into a triad or trivalent. On the contrary, accession DKN and DG-SB showed a linear and a regular tetrad after the disjoint at telophase II.

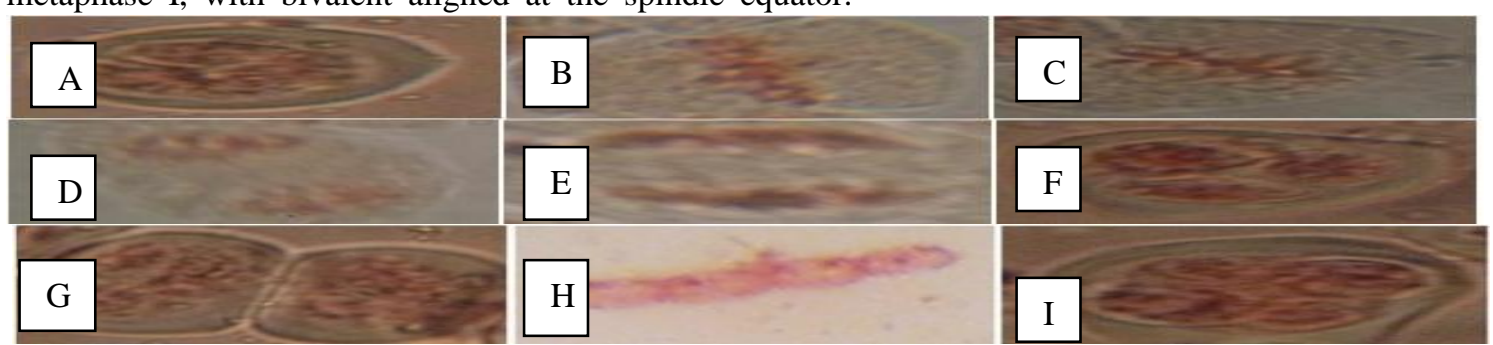

Plate 1: Cytological events: $A=$ Interphase, $B=$ Early metaphase $I, C=$ Late prophase,

$\mathrm{D}=$ Early anaphase, $\mathrm{E}=$ Late anaphase, $\mathrm{F}=$ Triad (at telophase), $\mathrm{G}=$ Dyad (interkinesis),

$\mathrm{H}=$ Linear tetrad at telophase, $\mathrm{I}=$ Telophas

Discussion and Conclusion

This research revealed that variations existed among the accessions in respect to agro-morphological traits studied. The variability that existed among the accessions in traits such as plant height, days to first flowering, fruit girth and numbers of fruit per plant, fruits shape, average seed weight per plant, average fruit weight per plant, number of branches per plant might be due to genetic make of the plant as well as soil type. This agrees with the work of Del et al. [10]; Magaet al. [14] who reported that, the variation observed in pepper genotypes are due to differences in plants, soil type and the effect of environmental factor of the experimental site. The phenotypic variations that existed among the ten pepper accessions could importantly be utilized in the crop breeding and improvement programme. Chromosomes behaviours during meiotic investigation explained the phases involving inheritance in the ten pepper accessions studied and how the observed traits are transmitted from one generation to another, while maintaining their gene combination which interacts in a functional adaptive manner. Findings from this research suggest that Germplasm from DKD-RD, DG-SB, DSKT-RD and DADAM could be further examined for breeding and improvement programme due to their outstanding performances in relation to high valued traits such as days to first flowering, number of branches per plant, number of fruits per plant and average fruit weight.

Recommendation

Based on the findings in this research work,it is recommended that breeders should collect germplasm from DKD-RD, DG-SB, DSKT-RD and DADAM for further breeding and improvement programme due to their outstanding performance which are related to high valued traits as well as their ability to adapt well to certain environmental conditions. Also farmers should collect improved varieties from these accessions to enhanced good production.

\section{REFERENCES}

[1] M. Joshi, Chilli Pepper Institute studies what's hot. Your life (USA Today). (2012). Archived on (12th March, 2012).

[2] G. J. H. Grubben, I. M. El-Tahir, Capsicum annuum L. In: Grubben, G. J. H., and Denton O. A. (Eds.). PROTA 2: Vegetables/Legumes. [CD-Rom]. PROTA, Wageningen, The Netherlands. (2004).

[3] P. W. Bosland, Votava. Peppers; vegetable and spice capsicums. CABI Publishing, Wallingford, United Kingdom. (2000), Pp. 204.

[4] N. Pabon-Mora, A. Litt, Comparative anatomical and developmental analysis of dry and fleshy fruits of Solanaceae, American Journal of Botany, 98 (9). (2011). Pp. 1415-1436.

[5] B. E. Okoli, J. O. Osuji, The Status of Research on the Cytogenetic of Nigerian Fruit Crop. Nigerian Journal of Botany,21 (2), (2008), 358-372.

[6] FAOSTAT. Food and Agricultural Organization of the United Nations Statistical Database, Rome, Italy. (2013). Available online at http://faostat.fao.org/site/339/default.aspx.

[7] A.O. Adetula, S. A. Olakojo. Genetic Characterization and Evaluation of Some Pepper Accessions Capsicum frutescens (L.): The Nigerian 'Shombo' Collections. American-Eurasian Journal of Agricultural and Environmental Science, 1 (3),(2006),273-281.

[8] N. Deepa, C. Kaur, B. George, B. Singh, B.,H. C. Kapoor, Antioxidant constituents in some sweet pepper (Capsicum annuumL.) genotypes 


\section{Profile of Author 3}

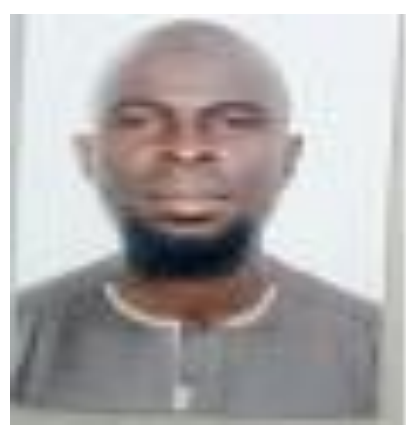

DaudaAyewale AYELEKE is a Senior Agricultural Officer in the Federal Ministry of Agriculture and Rural Development, Abuja, Nigeria. $\mathrm{He}$ is currently a $\mathrm{PhD}$ student at Federal University of Technology, Minna, Niger State. He has Postgraduate Diploma in Education (PGDE) at FCT College of Education, Zuba, Abuja in Affiliation with University of Maiduguri, Nigeria Master of Technology (MTech) in Agronomy at Federal University of Technology, Minna, Niger State. Bachelor of Technology (BTech) in Agronomy at LadokeAkintola University of Technology, Ogbomoso, Oyo State. He is a member of Genetics Society of Nigeria (GSN). His research areas are breeding for resistant varieties and grain quality in rice. He has 6 published journal papersto his credit.

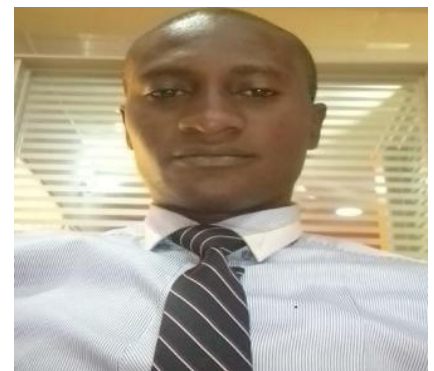

Elisha Bahu ISHAYA is currently working with AXA Pension Limited, Kaduna, NIGERIA. He is a Masterdegree holder (M.Tech) in Crop Production from Federal University of Technology, Minna, Niger State. Bachelor of Science (B.Sc) in Plant Science and Biotechnology from Nasarawa State University, Keffi. He is a member of Genetic Society of Nigeria (GSN). His area of research on breeding for resistance to Mould and Mycotoxinsand seed quality of vegetable crops.

\section{Profile of Author 2}

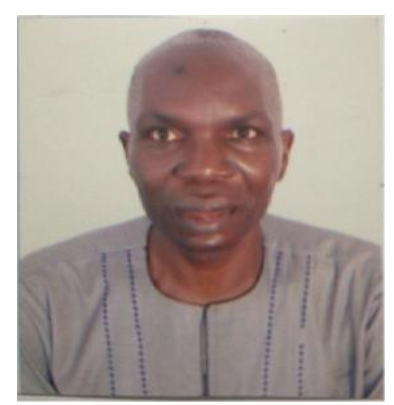

Andrew Saba GANA is a Professor of Plant Breeding and Genetics. He has BSc. (Agric.) 1987 from Usman Danfodio University,Sokoto. MSc. (Crop Production) University of Ilorin, PhD (Agronomy) from University of Ilorin. $\mathrm{He}$ became Professor in 2014 He was the HOD, Crop Production Department between 2011 and 2013. His research area is breeding for resistant varieties. He has bred improved varieties of rice. He has also identified genes for resistant to some biotic and abiotic stresses. He has supervised more than 30 undergraduate, about 15 masters and $10 \mathrm{PhD}$ students. He is member of Genetic Society of Nigeria, Association of seed scientist of Nigeria. He has published about 70 learned journals that covers the area of varietal improvement, resistant to biotic and abiotic stresses, varietal characterization. 